\title{
Türkçe T- K- denkliğinin Farsçadaki izleri
}

\section{Cihangir KIZILÖZEN1}

\begin{abstract}
APA: Kızılözen, C. (2019). Türkçe T- K- denkliğinin Farsçadaki izleri. RumeliDE Dil ve Edebiyat Araştırmaları Dergisi, (14), 33-54. DOI: 10.29000/rumelide.540993
\end{abstract}

\section{$\ddot{\mathbf{O z}}$}

Fars dilinde $t$ - ile başlayan birkaç sözcük, anlam değişikliğine uğramadan Türkçede $k$-ile başlar. Yine Farsçada $k$ - ile başlayan birkaç sözcüğün herhangi bir anlam değişikliğine uğramadan Türkçede $t$ - ile başladığı görülür. Bilindiği üzere $t$ ile $k$ ünsüzlerinin ses değerleri birbirinden farklıdır. Bu incelemede Türkçe-Farsça sözcüklerde görülen söz başı $t$ - $/ k$ - sorunu ele alınmıştır. Söz başı $t$-/k- denkliği Türkçenin kendi içinde saptanmış bir denkliktir. Ancak iki farklı dil ailesinden olan Türkçe ile Farsçada görülen söz başı $t$ - $/ k$ - denkliği daha önce ele alınmamıştır. Bu nedenle Türkçe ile Farsçada görülen söz konusu denkliği taşıyan sözcüklerin kökeni mercek altına alındı. İncelemede, Türkçe ile Farsçada $t$-/k- denkliği bulunan kırık "kırık" / terek "çatlak", / kabar "kabarmış yara" / tāvel "kabarmış yara", kırış- "kırışmak" / terenc- "kırışmak" gibi sözcüklerin hangi dile ait olduğu sorununa açıklık getirilmek istenmiştir. Bu doğrultuda söz konusu sözcüklerin kökeni dil aileleri düzeyinde ele alındı. Öncelikle $t$ - ve $k$ - denkliği bulunan sözcüklerin eski Türkçe ile eski İranî dillerdeki kullanımı araştırıldı. Daha sonra çalışmaya dâhil edilen Farsça sözcüklerin Hint-Avrupa kökenli olup olmadığı mercek altına alındı. Son aşamada Altay dillerinden Moğol, Tunguz, Japon ve Kore dillerinde, üzerinde durduğumuz Türkçe sözcüklerin kökteşlerinin kullanılıp kullanılmadı̆̆ araştırıldı. Böylece karşılaştırmalı yöntemin kullanıldığı bu incelemede sözcüklerin kökeniyle ilgili sonuç çıkarmamızda Altay dil ailesiyle Hint-Avrupa dil ailesi belirleyici oldu.

Anahtar kelimeler: Farsça-Türkçe ilişkisi, Türkçe-Farsça t-, k- denkliği, Türk-Fars dil ilişkisi.

\section{The traces of Turkish T-/K- equivalence in Persian language}

\begin{abstract}
Abstrac
In Persian language there are several words beginning with $t$ - which occur as words beginning with $k$ - in Turkish language without difference in their senses. Moreover, there are several words in Persian language beginning with $k$ - which occur as words beginning with $t$ - in Turkic language without difference in their meanings. As known phonetic values of the $t$ and $k$ consonants are different. Up to now, the problem of initial $t$ - $/ k$ - has not been dealt with in the relations of Turkish and Persian languages. In this review we wanted to explain this problem. In our investigation, examining modern and historical Turkic and Persian languages, discusses $t$ - $/ k$ - correspondence as it is observed in the words such as kırlk "broken"/ terek "fracture", tâvel "swollen wound" / kabar "swollen wound", kurıs- "to wrinkle" / terenc- "to wrinkle", kere "butter" / tere "butter". This study tries to answer the question of the source of this equivalence. Therefore, this equivalence of the words displaying t- and k- in the new Persian and new Turkish dialects are reviewed in ancient and early Persian languages end early Turkish resources too. Also, we searched the root of this words in the Indo-European language family and Altaic language family.
\end{abstract}

1 Dr. Öğr. Üyesi, Gümüsshane Üniversitesi, Edebiyat Fakültesi, Türk Dili ve Edebiyatı Bölümü, (Gümüşhane, Türkiye), cahangir@gmail.com, ORCID ID: 0000-0002-4202-1868 [Makale kaylt tarihi: 20.02.2019-kabul tarihi: 16.03.2019; DOI: $10.29000 /$ rumelide.540993] 
Key words: The relationship between Persian and Turkish, equivalence of t-, k- consonants, equivalence consonant in Turkish and Persian.

\section{Giriş}

Bir dilde kullanılan herhangi bir sözcük başka bir dilde kullanılan bir sözcükle tek bir sesbirimi ile ayrılabilir. Türkçede $t-e-r$ sesbirimlerinden oluşan ter ile Farsçada $s-e-r$ sesbirimlerinden oluşan ser sözcüğünü birbirinden ayıran $s$ - ve $t$ - ünsüzleridir. Burada ter "ter" ile ser "baş" sözcüklerini birbirinden ayıran sadece $t$ - ve $s$ - ünsüzleri değil, bu ikilinin anlamları da birbirinden ayrıdır. Bu durumda Türkçe ter kavramı ile Farsça ser kavramı arasında herhangi bir köken bağından söz edilemez. Kimi zaman da iki dilde tek bir ünsüzle birbirinden ayrılan, ancak ortak veya yakın anlamda kullanılan sözcükler bulunur. Bu gibi örneklerde görülen ses ve anlam ilişkisinin bir rastlantı sonucu geliştiği söylenebilir: Far. terek "çatlak" / Tür. kırık "kırık"

İki farklı dilde tek sesbirimle birbirinden ayrılan, eşanlamlı iki örneğin bulunması da doğal karşılanabilir: Far. terek "çatlak" / Tür. kırık "kırık”; Far. Tâvel "kabar” ～/ Tür. Kabar "kabarmış yara”.

Ancak iki farklı dilde ortak anlamda kullanılan birçok sözcüğün tek bir sesbirimle birbirlerinden ayrıldığına artık rastlantı denilemez:

Far. Tâvel "kabar" / Tür. Kabar "kabarmış yara"

Far. Terek "çatlak" / Tür. Kırık "kırı"”

Far. dūléx "fırtına" / Tür. külek "fırtına"

Yukarıdaki ikililerin ortak özellikleri şöyledir:

I. Hece saylları ortaktır (iki heceli).

II. Anlamları ortaktır.

III. Söz başı ünsüzler dışındaki bütün sesbirimleri yakın veya ortaktır.

Farsçada $\imath$ ünlüsü bulunmadığından Türkçe kırık sözcüğünde geçen 1 , Farsça terek sözcüğünde $e$ olarak kullanılmıştır. Yukarıdaki örnekleri birbirinde ayıran tek özellik, öz başı $t$ - ve $k$ - ünsüzlerinin birbirinin yerine geçmesidir. İşbu $t$-/ $k$ - ünsüzleri, söz konusu örneklerin anlamını değiştirmeden veya anlamsızlaştırmadan birbirlerinin yerine geçtiklerine göre birer alofon konumundadırlar. Başka bir deyişle eş değere sahipler, birbirlerinin dengiler. Örnek çiftler arasında görülen $t$ - $k$ - değişikliği, Türkçe ile Farsça arasında bulunan bir $t \sim k$ - denkliğinin göstergesi mi, yoksa ünsüz değişimi sonucunda mı ortaya çımıştır? Bu soruyu yanıtlamak için $t$ - $/ k$ - ünsüzleriyle birbirinden ayrılan daha çok Türkçe, Farsça örneğe ihtiyaç vardı.

I. Tür. Kırık: kırık ～～Far. Terek: çatlak

II. Tür. Kırış-: kırışmak ～～～Far. Terenc-: kırışmak

III. Tür. Küç: güç $\quad$ ～～Far. Tūş: güç 


\section{Tür. Külek: firtına $\quad$ Far. Dūléx: firtına \\ V. Tür. Tamak: damak ～～Far. Kāméh: damak \\ VI. Tür. Töş: döş, göğüs ～～Far. Keş: döş, göğüs}

Türkçe-Farsça sözcüklerde görülen söz başı $t$-/ $k$ - sorunu, bir ünsüz değişimi olarak değerlendirilebilirdi. Ancak Türk değişkelerinde saptanan söz başı $k$ - t- denkliği, Türkçe ve Farsça sözcüklerde görülen $t-/ k$ değişikliğinin bir ünsüz değişiminden kaynaklanmadığını gösterir. Türk değişkelerinde anlam ve ses değerleri ortak olup da sadece $t$ - $/ k$ - ünsüzleriyle birbirlerinden ayrllan sözcükler üzerinde bir inceleme yapılmıştır. Türk Dilinde $T$ - $K$ - Denkliği adlı incelemede eski ve yeni Türk değişkelerinde $t-/ k$ - denkliği bulunan on yedi sözcük tespit edilmiştir (Kızılözen 2018: 261-282): kırış- "kırışmak" tırış- "kırışmak"; kargl- "beddua etmek" targl- "beddua etmek"; kay- "kaymak" tay- "kaymak"; krpırda"kıpırdamak" tıpırla- "kıpırdamak" vb. Adı geçen incelemede birbirlerinin yerine geçen $t-/ k-$ ünsüzlerinin çok eskiden $t$ ve $k$ seslerini içinde bulunduran, yarı kapantılı bir ünsüzden geliştikleri sonucuna varılmıştır.<smiles>[Y]C[AlH]</smiles>

Farsça ile Türkçe arasında görülen söz başı $t$-/ $k$ - sorununun da bu bağlamda ele alınmasının doğru olacağı düşüncesindeyiz. Şöyle ki Türkçede $k$-li olan kimi sözcüklerin Farsçada $t$-li biçimiyle kullanılması, $k$->t- ünsüz değişiminin sonucunda ortaya çıkmış değildir. Söz konusu sözcüklerde görülen $t$-/ $k$ - değişikliği Türkçenin kendi içinde görülen bir ünsüz denkliğinin Türkçeden Farsçaya geçen sözcüklerdeki tezahürüdür. Başka bir deyişle söz konusu sözcükler Türkçenin herhangi bir eski değişkesinde $t$-li biçimiyle kullanılırken bir başka değişkesinde $k$-'li biçimiyle kullanılmıştır. Böylece Farsçaya da $t$-li ya da $k$-li olarak geçmiştir.

Türkçede $k$-'li, Farsçada $t$-'li olan sözcüklerin hangi dil ailesine ait olduğu konusunda bir kanıya varmak için karşılaştırmalı yöntem kullanıldı. Türkçe ile Farsça arasında $t$-/ $k$ - denkliği bulunan bütün sözcüklerin Hint-Avrupa kökenli olup olmadığı incelendi. Farsça kökenbilgisi çalışmalarında yer almayan veya Hint-Avrupa kökenli olduğu konusunda yeterli kanıtları bulunmayan örneklerle incelemenin bir sonraki aşamasına geçildi. Son aşamada Hint-Avrupa kökenli olmadıkları kesinleşen sözcüklerin Altay dil ailesinde kökleri araştırıldı.

\section{Kisaltmalar}

$\begin{array}{ll}\text { Az. } & \text { Azerbaycan } \\ \text { Baş. } & \text { Başkurt } \\ \text { Çuv. } & \text { Çuvaş } \\ \text { DLT. } & \text { Dîvân-i Lugati't-Türk } \\ \text { Dolg. } & \text { Dolgan } \\ \text { E. } & \text { Eski } \\ \text { Gag. } & \text { Gagauz } \\ \text { Hak. } & \text { Hakas } \\ \text { Hal. } & \text { Halaç } \\ \text { Kaz. } & \text { Kazak } \\ \text { KKlp. } & \text { Karakalpak } \\ \text { Kor. } & \text { Korece } \\ \text { Krg. } & \text { Kurgız } \\ \text { Krm. } & \text { Karay } \\ \text { Kum. } & \text { Kumuk } \\ \text { Moğ. } & \text { Moğol }\end{array}$

\author{
Nog. Nogay \\ O. Orta \\ Oyr. Oyrat \\ Öz. Özbek \\ Sal. Salar \\ SUyg. Sarı Uygur \\ Tat. Tatar \\ Tof. Tofalar \\ Trkm. Türkmen \\ TS. Türkçe Sözlük \\ Tuv. Tuva \\ Tür. Türkçe \\ Uyg. Uygur \\ Vb. Ve basska \\ Y. Yeni \\ Yak. Yakut
}




\section{İnceleme}

\section{Kabar Tāvel}

Yeni Farsçada tâvel تاول; yanık veya sürtünmeden kaynaklanan, çoğu zaman içinde su oluşan kabarıklık anlamında kullanılır (Moin 2002: 416). Farsça kökenbilgisi çalışmalarından Kâşânî ile Nourai sözlüklerinde bu sözcüğe yer verilmemiştir. Hassandoust çalışmasında ise bu sözcüğün sadece yeni İranî dillerden As, Beluç ve Gez dilleriyle Farsçanın Aliabad değişkesinde kullanılan biçimlerine yer verilmiştir. Hassandoust, tāvel sözcügünü, varlığı kanıtlanmamış tāv- "şiş-" köküne götürmüştür (Hassandoust 2016: 825). Farsça kökenbilgisi çalışmalarından yola çıkarak Farsçada kabarıklık anlamında kullanılan tāvel sözcüğünün Farsça kökenli olmadığını söylemek mümkündür:

I. Bu sözcük, Farsçayla ilgili yapılmış önemli üç kökenbilgisi çalışmasından ikisinde yer almamıştır.

II. Eski ve orta dönem İranî kaynaklarda bu sözcüğün izine rastlanmamaktadır.

III. Avrupa dillerinden tāvel sözcügüyle ilişkilendirilecek herhangi bir örnek sunulmamıştır.

IV. Tāvel sözcüğüyle ilişkili Sanskritçe örnek verilmemiştir.

V. Tāvel ile kökeni kanıtlanmamış bir sözcük arasında köken bağı ilişkisi kurulmuştur.

Yukarıda sıralanan hususlar dikkate alındığında tāvel sözcüğünün Hint-Avrupa kökenli olmadığı anlaşılıyor. $K$ - t- denkliği kapsamında Farsça tāvel ile Türkçe kabar arasında ses ve anlam ilişkisi kurmak mümkündür. Kabar ile tāvel sözcüklerini birbirinden ayıran üç ünsüz vardır. Bunlardan biri $b$ - ile $-v$ - ünsüzüdür. Her iki dilde $b>v$ değişimini gösteren birçok örnek vardır. Farsça $a \bar{b}$ "su" sözcüğünün İranî dillerde $o v$ olması, yine Eski Türkçe $s u b$ "su" sözcüğünün suv biçiminde gelişmesi bu bağlamda gösterilecek tipik bir örnektir. Tâvel ile kabar arasında görülen $r / l$ değişmesi de yine Türkçe ile Farsçada sık sık görülen bir ses olayıdır: Y. Far. tūleh "enik" tūreh "enik" (ES 2002: 501). Farsça kökenli servi sözcüğünün Türkçede selvi biçimiyle kullanılması da $r / l$ seslerinin birbirlerinin yerine geçebileceğini gösteriyor. Tāvel, kabar ikilisiyle ilgili üzerinde duracağımız gereken en önemli ses olayı $t$-, $k$ - ünsüzlerinin söz başında birbirlerinin yerine geçmesidir.

Azerbaycan Türkçesinde qabar; derinin altında oluşan sulu kabarcık anlamında kullanılır (Orucov, Abdullayev vb. III 2006: 8). Türk değişkelerinde kabar- sözcüğünden üretilen kavramların kabarkklk, şişme anlamlarında kullanıldığı tespit edilmiştir (Starostin, Dybo vb. 2003: 556). Araştırmacılar Moğol değişkelerinde siğil, kabarcık, sivilce anlamında kullanılan gövdrü, göbdör $\bar{u}$ biçimlerinin Türkçe kabar- ile ortak kökten geldiği kanısındalar (Starostin, Dybo vb. 2003: 555-56). Ayrıca Eski Japoncada ayaklardaki şişme anlamında geçen kofi ile Orta Korece'de ateş, sttma anlamında kullanılan kòpó-m sözcüklerinin de Türkçe kabar- ile ortak kaynaktan çıktığı ileri sürülmektedir (Starostin, Dybo vb. 2003: $556)$.

\begin{tabular}{|l|l|l|l|}
\hline Dil & Değişke & Biçim & Anlam \\
\hline $\begin{array}{l}\text { Ön Moğolca göb- / *güb-: } \\
\text { yükseklik, nesne yüzeyindeki } \\
\text { düzensizlik, siğil, kabarcık, }\end{array}$ & Yazı Moğ. & Göbdürigüü & Kabarck, siğil, sivilce \\
\cline { 3 - 4 } & Göbdurigüde- & Sivilce yap- \\
\hline
\end{tabular}




\begin{tabular}{|c|c|c|c|}
\hline \multirow[t]{3}{*}{$\begin{array}{l}\text { sivilce; sivilce yap-; tepe, } \\
\text { tümsek }\end{array}$} & Ordos Moğ. & Gobdor $\bar{u}$ & Kabarcık, siğil, sivilce, tepe \\
\hline & \multirow[t]{2}{*}{ Halha Moğ. } & Gövdrü & Kabarcık, siğil, sivilce \\
\hline & & Gövdrüüde- & Sivilce yap- \\
\hline \multirow{10}{*}{$\begin{array}{l}\text { Ön Türkçe *kāp-: kabarmak, } \\
\text { kabarcıklar oluşturmak; kalın } \\
\text { ve tepe }\end{array}$} & Orta Tür. & Qapar-, qabaq & Şiş-, kabarcıklar oluştur-, şişkin \\
\hline & Türkiye. Tür. & Kabar-, kaba & Şiş-, şişkin \\
\hline & Az. Tat. Tür. & Qabar-, qaba & Şiş-, kabarcıklar oluştur-, şişkin \\
\hline & Trkm. Tür. & Qābar-, qāaba & Şiş-, kabarcıklar oluştur-, şişkin \\
\hline & Başkurt Tür. & Qabar-, qaba & Kabarcıklar oluştur- tepe, höyük \\
\hline & Uygur Tür. & Qapa(r), qova & Şiş-, kabarcıklar oluştur-, şişkin \\
\hline & Nogay Tür. & Qabar- & Şiş- kabarcıklar oluştur- \\
\hline & Tuva Tür. & Xavar- & Şiş-, kabarcıklar oluştur- \\
\hline & Çuvaş Tür. & $X \mathfrak{z}_{n}$ ba-lan- & Şiş-, kabarcıklar oluştur- \\
\hline & Yakut Tür. & Xaba-lan- & Şiş-, kabarcıklar oluştur- \\
\hline 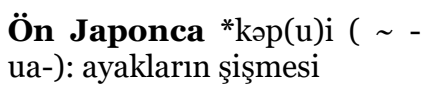 & Orta Jap. & Kofi & Ayakların şişmesi \\
\hline $\begin{array}{l}\text { Ön Korece *kòpó-m: ateş, } \\
\text { sitma }\end{array}$ & Orta Kor. & Kòpó-m & Ateş, sitma \\
\hline
\end{tabular}

Çizelge: 1

\section{Kaç- Tāç-/tāk-/tāz-}

Farsçada tāx- تاختن, tāz- تازيدن; koşmak anlamında kullanılır (Moin 2002: 413). Bu sözcük Pehlevi kaynaklarında $t a \overline{c ̧}$ - biçiminde geçer (Ferehveşî 2002: 540). Kâşânî çalışmasında, tāx- ile Yunan ve Latin dillerinde porsuk ağacı anlamında kullanılan birçok sözcük arasında ilişki kurulmuştur. Ayrıca yazar Eski İrlandaca, Bretonca ve Keltçede kaçmak anlamında kullanılan tecim, tebet ve te'çet sözcüklerini de Farsça $t \bar{a} x$ - ile ortak kökene bağlamıştır (Kâş̧ânî 2005: 187-88). Nourai çalışmasında bu sözcükle çizelgede gösterilen sözcükler arasında ilişki kurulmuştur (Nourai 2013: 468):

\begin{tabular}{|l|l|l|l|l|l|}
\hline Dil & \multicolumn{2}{|l|}{ Avestaca } & E. Farsça & O. Farsça \\
\hline Biçim & tak, taka, taç & vi-taxti & taçar, taçan, tahra & Taxşa & handâçak \\
\hline Anlam & koş- & eri- & yol, acele, hizlı & bir çeşit yay ile ok & at-, ölç- \\
\hline
\end{tabular}

Çizelge: 2

Farsça kökenbilgisi çalışanlarından Hassandoust, tāz- sözcüğünü tāx- "koş-" başlığı altında ele alarak aşağıdaki sözcüklerle ilişkilendirmiştir (Hassandoust 2016: 804-805). 


\begin{tabular}{|l|l|l|l|l|l|}
\hline Dil & Biçim & Anlam & Dil & Biçim & Anlam \\
\hline Sanskritçe & $t a k-$ & acele et-, koş- & Soğdca & tyyh & Irmak \\
\hline Avestaca & tak- & koş- & Sakaca & ttajs- & koş- \\
\hline Orta Farsça & taz- & koş-, ak- & Peştunca & tej-, tōe & koştur-, , urmak \\
\hline Orta Farsça (Turfan) & tz- (taz-) & dök-, ak & Beluçça & taç- & koş- \\
\hline
\end{tabular}

Çizelge: 3

Yazar daha sonra İranî dillerde $a k$-, ırmak anlamında kullanılan birçok sözcükle Farsça tāk- "koşmak" arasında köken bağı ilişkisi kurmuştur. Farsça kökenbilgisi çalışmalarında koşmak anlamında kullanılan tāk-, tāç-, tẫz- değişenleriyle ileri sürülen görüşler bu sözcügün Hint-Avrupa kökenli olduğunu gösterecek nitelikte değildir.

I. Farsça üç kökenbilgisi çalışmasından ikisinde Farsça tāk-, tāz- sözcüğü Avrupa dillerinden herhangi bir sözcükle ilişkilendirilmemiştir.

II. Kâşânî çalışmasında Yunan ve Latin dillerinde porsuk ağacı anlamında kullanılan sözcüklerle tāxarasında kurulan anlam ilişkisi doğru değildir.

III. Onlarca Avrupa dilinden sadece üç örneğin Farsça tāx - ile ilişkilendirilmesi yeterli değildir. Eski İrlandaca tecim, Bretonca tebet ve Keltçede te'çet ile tāx- arasında görülen ses ve anlam ilişkisi bunların ortak kökenden çıktığını göstermez. Söz konusu sözcüklerle tāx- arasındaki benzerlik bir rastlantı sonucunda ortaya çıkmış olabilir. Ayrıca söz konusu sözcükler başka bir dil ailesinden de alınmış olabilir.

Öncelikle Hint-Avrupa dillerinin Hint-İran kollarında $c ̧ / k$ ünsüzlerinin yer değiştirdiğini belirtmek isteriz (Jackson 1892: 28). Sanskritçe tak- ile Orta Farsça tāç- sözcüklerinde görülen $-k /-c ̧$ farklılığı bu bağlamda değerlendirilmelidir: Sanskritçe tak-, Avesta- tak- Orta Farsça tāç-. Eski ve orta dönem İranî dillerde kullanılan kimi ç ünsüzlerinin orta dönem İranî dillerden itibaren $z$ ile yer değiştirdiği bilinir (Ḥânlerî 1998: 77): Orta Farsça tāç- > taz- > Yeni Farsça tāz-.

$T$ - k- denkliği bağlamında Pehlevice tāç- ile Türkçe $k a c ̧$ - sözcüklerinin ses ve anlam değerleri örtüşür. ${ }^{2}$ Kaç- sözcüğü, çağdaş Türk değişkelerinden Türkiye, Azerbaycan, Türkmen, Özbek, Uygur, Tatar, Başkurt, Kırgız, Kazak, Karakalpak, Kumuk, Nogay, Hakas, Şor, Oyrot ve Tuva Türkçelerinde kullanılmaktadır (Starostin, Dybo vb. 2003: 751-52). Ayrıca bu sözcük, Eski ve Orta Türkçede de yine kaç- biçiminde kullanılmıştır (Gülensoy 2011: 449). Kaç- sözcüğü ile ortak kaynaktan çıktığı düşünülen sözcüklerin Tunguz ve Moğol (Starostin, Dybo vb. 2003: 751) dillerinde kullanılıyor olması bu sözcüğün Türkçeden Farsçaya geçtiğini gösteriyor.

Türkçe kaç- ile Farsça tāzi- arasında görülen $-c ̧ ~ \sim ~-z$ değiş̧ikliğini Türkçenin kendi içinde de görmek mümkündür. Kimi Türk değişkelerinde kaç- anlamında kullanılan bir de tez- (Starostin, Dybo vb. 2003: 1429) sözcüğü vardır. Çağdaş Türk değişkelerinde kullanılan tez- "kaç-" sözcüğünün Ön Türkçe *tērbiçiminden çlktığı düşünülmektedir (Starostin, Dybo vb. 2003: 1429). T- k-denkliği kapsamında

2 Azerbaycan Türkçesi ile İran Türk ağızlarında kaç- kavramı koçmak ve kaçmak anlamlarında geçer. 
Türkçeden İranî dillere geçen tāç- "koş-", Yeni Farsça yoluyla Türkçeye tazı "hızh koşan köpek" biçiminde geri dönmüştür.

\section{Kapak > Tābeh}

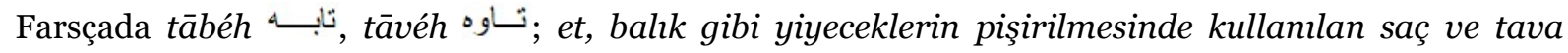
anlamında kullanılır (Moin 2002: 408). Vâjéhâ-yé Fârsî-yé Erebî Şode "Arapçalaşmış Farsça Sözcükler" adlı çalışmada elțābak الطـابق sözcüğünün Farsçadan Arapçaya geçtiği bilgisi yer almaktadır (Esverî 2007: 166). Arapçadaki Farsça kökenli sözcükleri inceleyen Ferheng-é Vâjéhâ-yé Fârsî Der Erebî “Arap Dilinde Farsça Kavramlar Sözlüğü” adlı çalışmada da طـ țābak sözcügüünün Farsça kökenli olduğu ileri sürülmüştür (Şûşterî 1968: 444).3 Arapçaya geçmiş Farsça kavramları inceleyen çalışmalarından yola çıkarak tābéh sözcüğünde bir $-k>-h$ ünsüz değişiminin gerçekleştiğini söylemek mümkündür. Farsça tābéh/tāvéh sözcüğünün sonunda bulunan - $h$ ünsüzünün $-k$ ünsüzünden geliştiğini gösteren bir başka örnek de tebūk sözcüğüdür. Emîd Sözlüğü’nde tebūg تَّ ; yemek veya meyve yemek için kullanılan kenarları çıkntıll, yuvarlak, ağaç veya demir kap anlamında geçer (Emîd 2010: 374). Tābéh, tāvéh; tebūk ve tābek sözcükleri arasında görülen ses ve anlam ilişkisi bu sözcüklerin ortak kaynaktan çıktığını gösteriyor.

İncelediğimiz Farsça kökenbilgisi çalışmalarından Hassandoust Sözlüğü'nde tābeh “tava” ile Orta Farsça tāb- "parlamak, ateşte demiri kızartmak" arasında köken bağ ilişkisi kurulmuştur (Hassandoust 2016: 801). An Etymological Dictionary of Persian, English and other Indo-European Languages adl çalışmada tābeh ile tābe, tāb, teb; tāầ-, tāfi-, tepī- sözcükleri ortak kökene bağlanmıştır (Nourai 2013: 473). Bunlardan tābe, tāb, teb "ateş"; tābî-, tâfi- parlamak, ısınmak, çırpınmak anlamı taşıdıklarından söz konusu sözcükle ilişkili olamaz. Râhnémâ-yé Rîseé-yé Félhâ-yé İran̂̂ "İranî Fiillerin Kökeni Kılavuzu” çalışmasında tābéh sözcü̆üu, parlamak, çırpınmak anlamındaki tābi- ve tepi- köküne bağlanmıştır (Mokaddem 1963: 45). Ancak tābi- ve tepi- "parlamak, çırpınmak" sözcükleriyle de tābéh arasında herhangi bir anlam ilişkisi bulunmamaktadır. Etymological Dictionary of the Iranian Verb "İranî Fiiller kökenbilgisi Sözlügüu” çalışmasında Avesta dilindeki tap- "Isınmak", Orta Farsçadaki tāb"isınmak, yakmak", Hotencedeki ttav- "sıcak olmak", Soğdcadaki t'b- "mühürlenmek"; 'tpn "firın”; pt $\beta$ "yanmak"; wyt"p- "parlamak" (Cheung 2007:378-79) kavramları üzerinde durulmuştur. Ancak söz konusu eserde belirttiğimiz sözcüklerden hiçbiri tābéh/tābek/tebūk ile ilişkilendirilememiştir.

Kökenbilgisi çalışmalarında tābéh/tābek/tebūk sözcüğünün Hint-Avrupa kökenli olduğunu gösterecek sağlam kanıtların sunulmadığı görülür. Herhangi bir sözcükle ilgili bir yargıya varmak için o sözcüğün en küçük anlamlı birimine ulaşılmalıdır. Orta Farsçada sonu $-k /-k$ ile biten birçok sözcüğün Yeni Farsçada $-k,-k>h$ değişimine uğradığı ancak Arapçaya geçen Farsça sözcüklerde bu değişiminin gerçekleşmediği görülüyor. Başka bir deyişle Farsçadan Arapçaya geçmiş sözcüklerin ses değerleri korunmuştur. Söz sonu - $k>-h$ değişimi dikkate alındığında tābek, țāba $k$, țābek, tebek biçimlerinin tābeh, tâveh biçimlerinden daha eski olduğu anlaşıllyor. Tābek, țâba $k$, țābek değişenlerinin ilk hecesi olan tāb/țāb-, bu kavramın anlamlı birimi olarak düşünülebilir.

Tāb-, țâb- değişenleriyle Türkçe tap- sözcüğünün ses değerleri örtüşüyor. Ancak Türkçede tapmak, bulmak anlamında kullanılan tap-, ile Farsça tāb(ek), tâa $b(\bar{a} k)$, teb( $\bar{u} k)$ değişenleri arasında herhangi bir Türkçe Sözlükte tabak sözcüğü köken olarak Arapça gösterilmiştir. Ancak Farsça sözlüklerde bu sözcüğün Farsça kökenli
oldugu belirtilir. 
anlam ilişkisi kurulamaz. Ancak söz başı t- k- denkliği bağlamında ele alındığında Türkçe kap ile Farsça $t \bar{a} b(e k), t a \bar{a} b(\bar{a} k), t e b(\bar{u} k)$ sözcükleri arasında bir ilişkiden söz edilebilir.

Orta Farsçadaki tābek "saç, tava, tabak" sözcüğünün anlamı ile Türkçe kap "kap kacak" sözcüğünün anlamı ortaktır. Türkçe Sözlük'te kap: içi gaz, sıvı veya katı herhangi bir maddeyi alabilen oyuk nesne ve kap kacak anlamında geçer. Altay dillerinden Tunguz, Moğol ve Japon dillerinde Türkçe kap ile ortak kaynaktan çıtığı düşünülen sözcüklerin kullanılıyor olması bu sözcüğün Türkçe kökenli olduğunu gösteriyor (Starostin, Dybo vb. 2003: 646-47). Eski Uygur Türkçesinde kap; torba anlamında kapçuk ise keten torba anlamında geçer (Caferoğlu 1993: 110). Divan-ü Lügat-it Türk’te kap; kap, tulum, çuval, zarf (DLT 1999: 262); kapçak ise su kollarmmn birbirine kavuştuğu yer olarak geçer (DLT 1999: 262). Kap/qap sözcüğünün herhangi bir ek almadan Türkiye, Azerbaycan, Tatar, Türkmen ve Uygur Türkçesinde kullanıldığı aşağıdaki çizelgede gösterilmiştir (Starostin, Dybo vb. 2003: 646-47).

\begin{tabular}{|c|c|c|c|}
\hline Dil & Değişke & Biçim & Anlam \\
\hline \multirow{8}{*}{$\begin{array}{l}\text { Ön Tunguzca: } \\
\text { *kup-: kapa-, klllf, } \\
\text { çuval, diz kapağl, } \\
\text { kapak }\end{array}$} & \multirow[t]{2}{*}{ Evenki } & Kuptu-, kupu- & Kapa- \\
\hline & & Kupu, küpe, kupō & Kapak, giysi, diz kapağı \\
\hline & Even & Kupke, kubi, quptu, & Çuval, diz kapağı, şapka, \\
\hline & Negidal & Kuptin-, koptịn & Kapa-, kapak \\
\hline & Mançu & Xubtu & Pamuklu ceket \\
\hline & Ulça & Кир & Kapa- \\
\hline & Orok & Quptu-, qōpomi & Kapa-, giysi \\
\hline & Nanai & Koptö & Killf \\
\hline \multirow{5}{*}{$\begin{array}{l}\text { Ön Moğolca } \\
\text { *kab-: çuval }\end{array}$} & Yazı Moğ & Qabta-ya(n) & Çuval \\
\hline & Halha & Xavtga & Çuval \\
\hline & Kalmuk & Xaptəxə & Çuval \\
\hline & Dagur & Xartag & Çuval \\
\hline & Ordos & GabtarGa; & Çuval \\
\hline \multirow{7}{*}{$\begin{array}{l}\text { Ön Türkçe *kāp: } \\
\text { çuval }\end{array}$} & Orta Tür. & Qap & Kap \\
\hline & Tür. Tür. & Kap, kapa- & Kap, kapa- \\
\hline & Az. Tofalar & $Q a b, q a b$ & Kap \\
\hline & Trkm. & Gāp, Gāba- & Kap, sarmak \\
\hline & Uyg., Tat., Baş., Kır. Kaz. & Qap & Çuval, kap \\
\hline & Tuva & Xap & Kap \\
\hline & Yakut & Xappar & Kap, çuval \\
\hline
\end{tabular}




\begin{tabular}{|l|l|l|l|}
\hline \multirow{2}{*}{$\begin{array}{l}\text { Ön Jàmpú-: } \begin{array}{l}\text { Oaponca } \\
\text { şapka }\end{array} \\
\text { kask", }\end{array}$} & Eski Jap. & Kabut(w)o & Kask \\
\cline { 2 - 4 } & Orta Jap. & Kàbuto; & Kask \\
\cline { 2 - 4 } & Tokyo & Kábuto & Kask \\
\cline { 2 - 4 } & Kyoto & Kábútó & Kask \\
\cline { 2 - 4 } & Kagoşima & Kabutó & Kask \\
\hline
\end{tabular}

Çizelge: 4

Kap sözcüğüyle ilişkili olduğunu düşündüğümüz bir başka sözcük kabuktur. Ön Türkçede *kāpuk (Starostin, Dybo vb. 2003: 764) biçiminde kullanıldığı düşünülen sözcükle ile kap arasındaki ses benzerliği dikkat çekiyor. Bu ikilinin anlam değerleri arasında da bir ilişki mevcuttur. Bir nesneyi çevreleyen, bir nesnenin dış örtüsü konumunda bulunan kabuk, aslında bir tür kap işlevini yerine getirmektedir. Kabuk sözcüğü ile ortak kökenden çıtığı düşünülen sözcüklerin Tunguz, Moğol, Japon ve Kore dillerinde kullanılıyor olması, bu sözcügü̈n de Türkçe kökenli olduğunun göstergesidir (Starostin, Dybo vb. 2003: 764).

Kap kavramının Türkçe kökenli olduğunu gösteren bir başka örnek Ana Türkçede * Kapırçak, * Kapsak "kutu, tabut" olarak tahmin edilen daha sonra Karahanlı Türkçesinde qaprrçaq biçiminde yer alan sözcüktür. Türkiye Türkçesi ağızlarında kaburcuk, kaburcak, kabzak, kapsak; Türkmen Türkçesinde Gaprcaq; Çuvaşçada koporso biçimleri ile kullanılan sözcüğün Ana Türkçede ${ }^{*} K a p ı r c ̧ a k, ~ * K a p s a k$ biçimlerinden çıktığı düşünülmüştür (Starostin, Dybo vb. 2003: 763).

T- t- denkliği bağlamında Farsça tābéh (<tābek) sözcüğüyle ilişkili olduğunu düşündüğümüz en önemli sözcük, Türkçe kapak sözcüğüdür. Türkçe Sözlük'te kapak; her türlü kabın üstünü örtmeye veya bir deliği kapamaya yarayan nesne olarak geçer. Yukarıda tābéh, tāvéh, țābak ve tebūk sözcüklerinin

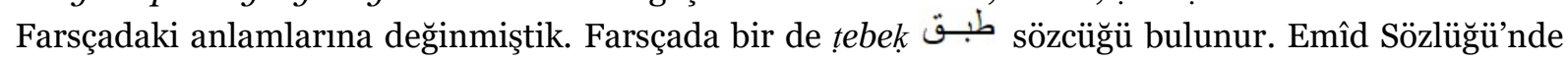
tebek sözcüğü için iki anlam verilmiştir (Emîd 2004: 842): 1. Kapak 2. Ağaç tabak.

Söz başı $t$ - k- denkliği bağlamında tabak (>țebek) ile kapak sözcüklerinin aynı kökten geldiğini düşünüyoruz. Aradaki $p, b$ karşıtlığı da yine bir $p>b$ değişiminin sonucudur: tabak < tapak $\sim$ kapak. Bu bağlamda Kırgız Türkçesinde göz kapağı anlamında kullanılan kabak (< kapak) sözcüğü örnek verilebilir. Kapak/tabak ikilisinin ses özellikleriyle birlikte göndermede bulundukları nesneler de birbirine benzemektedir. Başka bir değişle kapak ile tabak ikilisinin anlamlar ortaktır.

\section{Kapak da tabak da birer kap saylır.}

II. Kapak da tabak da kazan veya tencere gibi derin değildir.

III. Kapak özel olarak bir nesnenin başını kapatmak için kullanılmaktadır. Ancak bir tabağın da çoğu zaman bir kapak yerine kullanıldığını görmek mümkündür. Dolayısıyla işlevleri ortaktır.

IV. Bir kabın üstünü kapatmak için kullanılan kapak, yemek yemek için kullanıldığında tabak işlevini yerine getirmiş olur.

V. Büyük bir oranda ikisi de yuvarlaklar 
VI. Türkçede $t$ - ve $k$ - denkliği, bir ünsüz parçalanmasının sonucunda ortaya çıkmıştır diye düşünüyoruz. Büyük bir olasılıkla $t$ ve $k$ ünsüzünü barındıran *tk gibi bir yarı kapantılı ünsüzün parçalanmasından $\mathrm{t}$ ve k ünsüzleri doğmuştur.

$\underline{\text { TKapak }}\left[\begin{array}{l}\text { Tabak } \\ \text { Kapak }\end{array}\right.$

Ses ve anlam bakımından tabak ile ilişkili olduğunu düşündügümüz kapak sözcüğünün Türk değişkelerinin yanı sıra Altay dillerinde çeşitli biçimleriyle kullanılıyor olması bu sözcüğün Altayca, dolaysıyla Türkçe kökenli olduğunu gösteriyor (Starostin, Dybo vb. 2003: 765).

\begin{tabular}{|c|c|c|c|}
\hline Dil & Değişke & Biçim & Anlam \\
\hline \multirow{3}{*}{$\begin{array}{l}\text { Ön Tunguzca } \quad * \quad \text { xapki-: } \\
\text { engelle- }\end{array}$} & Ulça & Xaqpali & Engelle- \\
\hline & Orok & 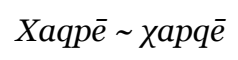 & Engelle- \\
\hline & Nanai & Xaqpi- & Engelle- \\
\hline \multirow{5}{*}{$\begin{array}{l}\text { Ön Moğolca * kaya-: engelle-, } \\
\text { kapa- }\end{array}$} & Orta Moğ. & Qa'a- & Engelle-, kapa- \\
\hline & Yazı Moğ. & Qaya- & Engelle-, kapa- \\
\hline & Hal. Bur. Kalm. Ord. Bao. & $X \bar{a}-$ & Engelle-, kapa- \\
\hline & Dagur Moğ. & $X \bar{a}-, h \bar{a}$ & Engelle-, kapa- \\
\hline & Dongxian & $Q \bar{a}-$ & Engelle-, kapa- \\
\hline \multirow{11}{*}{$\begin{array}{l}\text { Ön Türkçe *kap-: kapak, kapı, } \\
\text { kapamak }\end{array}$} & Eski Tür. & Qapaq & Kapak \\
\hline & Orta Tür. & Qapyaq & Kapak \\
\hline & Tür. Tür. & Kapak & Kapak \\
\hline & Az. Tür. & GapaG & Kapak \\
\hline & Trkm. Tür. & Gapaq & Kapak \\
\hline & Öz. Tür. & Qэрєqэq & Kapak \\
\hline & Uyg. Tür. & $\operatorname{Qap}(q) a q$ & Kapak \\
\hline & Kirg. Kaz. Tat. Tuv. Oyr. & Qapqaq & Kapak; kapı \\
\hline & Hakas Tür. & Xaxpax & Kapak \\
\hline & Çuvaş Tür. & Xobz; op(la)- & Kapak, kapa- \\
\hline & Yakut Tür. & Xappax & Kapak \\
\hline Ön Japonca *kupai: çit & Eski Jap. & Kupe & Çit \\
\hline
\end{tabular}

Çizelge: 5 
Türk değişkelerinde kullanılan kap, kapı, kapak ve kabuk sözcükleri, Ana Türkçedeki *kāp- köküne gidiyor. Türkçe kapak, kapı, kap- ve kapa- ile kökteş olan sözcüklerin Altay dillerindeki kullanımı bu sözcüklerin Türkçe olduğunu gösteriyor (Starostin, Dybo vb. 2003: 765). Türkçenin kendi içindeki $t-\sim k-$ denkliği ile Türk-Fars dilleri arasında tespit edilen bu denklik, tabak kapak sözcüklerinin birer değişen (varyant) olduklarını gösteriyor. Özellikle kap kacak anlamında değerlendirildiğinde bu ikilinin anlam ilişkisi de bunların ortak kökten çıktığını onaylar niteliktedir. Ayrıca ses ve anlam bakımından kapak sözcüğü ile ilişkili olan kap, kap-, kapa-, kapı, kabuk, kovan, kovuk (< kabuk) "sidik torbası" gibi sözcüklerin Altay dillerindeki kullanımı, kapak sözcüğünün Türkçe bir sözcük olduğunu kanıtllyor.

Burada biçim ve anlam yönüyle Türkçe kap-, kapak sözcüklerini ilgilendiren Hint-Avrupa dillerindeki birkaç sözcüğe değinmeden konuyu kapatmak istemiyoruz. Ana Hint-Avrupacada kapamak anlamında kullanıldığı düşünülen bir ${ }^{*} k a p$ - sözcü̆ğünün varlığından söz edilmektedir. Arnavutçadaki kab"kapamak”, Eski Hintçedeki kapatī "avuç”, Farsçadaki çespi-, çepsi- "yapışmak" sözcükleri Ana HintAvrupa dilinde * $k a b$ - biçiminde kullanıldığı düşünülen sözcüğe bağlanmaktadır. Ana Hint-Avrupa dilindeki farazî * $k a b$ sözcüğü ile ilişkilendirilen örnek sözcükler şunlardır (Pokorny 2007: 1446).

\begin{tabular}{|c|c|c|}
\hline Dil & Biçim & Anlam \\
\hline Eski Hin. & Kapatī & Avuç \\
\hline Eski Far. & Çepsī, çespi- & Yapış- \\
\hline \multirow[t]{2}{*}{ Yunanca } & Калغ́тıৎ & Kapasite ölçümü \\
\hline & 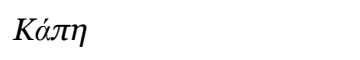 & Beşik, yemlik \\
\hline \multirow[t]{2}{*}{ Arnavutça } & Kap & Yakalamak \\
\hline & Kapasë & Yağ kabı \\
\hline Latince & Capiō, -ere, cēpī, captus & Almak \\
\hline
\end{tabular}

Çizelge: 6

Çizelgede yer alan örneklerden hiçbiri:

I. Tabak/Kapak arasındaki ses ve anlam ilişkisini yadsıyamaz.

II. Tabak/Kapak arasında görülen ses ve anlam benzerliği/ortaklığı Hint-Avrupa kökenli hiçbir sözcükte bulunmamaktadır.

III. Ana Hint-Avrupa dilindeki *kab- "kapamak" ile bağlantılı olduğu düşünülen kimi sözcüklerin ses ve anlam ilişkisi güvenilir değildir. Bu bağlamda Farsça çepsī- "yapışmak" sözcüğü örnek verilebilir. Türkçe-Farsça ilişkisinde söz başı ç-/y- değişikliği esas alınırsa çepsī- "yapışmak" sözcü̆üu ile Türkçe yapış- "yapışmak” arasında daha sağlam ilişki kurulabilir.

IV. Kap- sözcüğünün Altay dillerindeki kullanım alanı Hint-Avrupa dillerindeki kullanım alanından daha geniştir. 
Bütün bunlara rağmen Ana Hint-Avrupa dilinde kullanıldığı düşünülen *kab- ile Ana Altay dilinde kullanıldı $\breve{g}$ düşünülen *kap- arasındaki ses ve anlam ilişkisi de görmezden gelinemez. Bu ilişkinin iki yönde açıklanması mümkündür:

I. *kab/*kāp sözcügü, Ana Hint-Avrupa dilinden Ana Altay diline geçebileceği gibi Ana Altay dilinden de Ana Hint-Avrupa diline geçmiş olabilir.

II. Avrasyatik dil ailesi kapsamında düşüldüğünde her iki dil ailesine ait bir sözcüktür denebilir. Ancak J. H. Greenberg'in Avrasyatik dil ailesinde kullanılan ortak sözcüklerle ilgili yaptığı Indo-European an Its Clossest Relatives The Eurasiatic Family adlı çalışmasına kāp sözcügünün yer almadığını belirtmek isteriz.

Bizim görüşümüz, kap sözcüğünün Altayca kökenli olduğu yöndedir. Ana Hint-Avrupaca * kab ile ilişkisi sağlam olan bir örnek vardır. Bu örnek Arnavutçadaki kap- "almak" sözcüğüdür. Arnavutça kap-, Türkçeden alıntı olabilir. Bu durumda Ana Hint-Avrupa dilindeki farazî * $k a b$ - sözcüğünü destekleyecek hiçbir örnek kalmıyor. Ana Hint-Avrupa dilindeki *kab- sözcüğünün varlı̆̆ı doğru olsa bile Türkçe kapak ile İranî dillerdeki tapak arasındaki ese ve anlam ilişkisi ortadan kalkmıyor. Bu durum da söz konusu sözcüğü Avrasyatik bir kökene götürür. Başka bir deyişle kap-, Altay dil ailesi ile Hint-Avrupa dil ailesinin ortak sözcügüuür denebilir. Ne kadar kap sözcüğü Avrasyatik dillerin ortak sözcüğü olsa da kapak sözcüğü Türkçenin bir ürünüdür. Bu bağlamda uçak sözcüğünün Azerbaycan ve Kazak Türkçelerindeki kullanımı örnek verilebilir. Türkiye Türkçesinde tayyare yerine uçak kullanılmaktadır. Azerbaycan Türkçesiyle Kazak Türkçelerinde daha önceleri Rusça самолет "samolyet" kullanılıyordu. Ancak artık samolyet yerine Azerbaycan Türkçesinde uçaq, Kazak Türkçelerinde uşak kullanılmaktadır. Söz konusu Türk değişkelerinde uç-/uş- sözcüğü ortaktır. Ancak uç- kökünden üretilen uçak sözcüğü Türkiye Türkçesinden alınmıştır.

$T$ - k- denkliği kapsamında Türkçeden alınan tabak (< *tapak) sözcüğü, daha sonraya Türkçeye tava ve tabak olarak geri dönmüştür. Tava sözcüğü doğrudan Farsçadan, tabak ise Arapça yoluyla Türkçe dönmüştür.

\section{Kere $\sim$ Tere(yağı)}

Fars dilin kere $ه$ كر; tereyağı anlamında kullanılır (Moin 2002: 1353). Kâşânî çalışmasında tereyağ anlamında kullanılan kere sözcüğü yer almamıştır. Bu sözlüğün giriş bölümünde Farsça kökenli olduğu kanıtlanmamış sözcüklere yer verilmediği belirtilmiştir. Bu sözcüğe Nourai çalışmasında da yer verilmemiştir. Hassandoust, kereh “tereyağı” sözcüğüyle aşağıdaki sözcükleri ortak kökene bağlamıştır.

\begin{tabular}{|l|l|l|l|l|l|l|l|l|}
\hline \multicolumn{1}{|l|}{ İranî Diller } & \multicolumn{3}{l|}{ Avrupa Dilleri } \\
\hline O. Fars & Asça & Hansarca & Bahtiyarca & Göranca & Aştiyanca & Latince & E. İngilizce & E. Slav. \\
\hline Kār & garak & kīrä & Kerra & Kärrä & Karra & cāseus & hwæg & kvasûu \\
\hline tereyağı & $?$ & tereyağı & $?$ & $?$ & tereyağı & peynir & peynir suyu & hamur \\
\hline
\end{tabular}

Çizelge: 7

İki önemli kökenbilgisinde Farsça kere sözcüğüne yer verilmemesi bu sözcüğün Hint-Avrupa kökenli olduğu konusunda yeterli kanıt bulunmadığının sonucu olsa gerek. Hassandoust çalışmasında ise kere 
sözcüğüyle ilişkili Avrupa dillerinden gösterilen örneklerin sayısı sınırlıdır. Ayrıca gösterilen örneklerle kere arasındaki anlam ilişkisi de kesin değildir. Ayrıca eski ve orta dönem İranî dillerde bu sözcü̆üun kullanıldığına dair herhangi bir bilgi mevcut değildir.

Türkçe Sözlük’te tereyağı; sütten çıkarılan taze yă̆ anlamında geçer (TS 1998: 2197). Tereyağı sözcüğündeki tere bölümünü, Farsçada bir bitki adı olan tere ile ilişkilendiren Eyuboğlu, bu sözcüğün anlamını da yeşil ot yiyen, yaylımda otlayan ineklerin sütünden alınan yă̆ (Eyuboğlu 1991: 656) olarak vermiştir. Clasoun'un An Etymological Dictionary of Pre-Thirteenth Century Turkish adlı çalışmasıyla Gülensoy’un Türkiye Türkçesindeki Sözcüklerin Köken Bilgisi Sözlüğü’nde tereyağı ile ilgili herhangi bir bilgi yer almamıştır.

Tereyağı sözcügündeki tere parçasının Farsça tere "tere” sözcüğünden geldiği yaklaşımı birkaç yönden sorunludur. Birincisi tereya ̆̆ herhangi bir bitkiden değil de sütten elde edilir. İkincisi ise tere sözcüğü, Farsçada da Türkçede de insan tarafından yenilen bir ot olup genel olarak bütün bitkileri içine alan bir kavram değildir. Hayvanların tereyağı yapılacak süt vermeleri için tere adındaki özel bitkiyi yemelerine de gerek yoktur. Üstelik İran Türk ağızlarında4, Azerbaycan Türkçesinde (Orucov, Abdullayev vb. III 2006: 686) ve Farsçada (ES. 2004: 973) kere sözcügü̈, tek başına tereyağı anlamında kullanılmaktadır. Ayrıca kere sözcüğünün Azerbaycan Türkçesinde de İran Türk ağılarında da Farsçada da bitki anlamı bulunmamaktadır. Dolayısıyla tereyağı sözcüğünde geçen tere parçasının bitki anlamındaki Farsça tere ile değil de İran Türk ağızlarıyla Azerbaycan Türkçesinde, yine Farsçada tereyağı anlamında kullanılan kere ile bağlantılı olduğu söylenebilir.

Azerbaycan Türkçesinde, İran Türk ağızlarında ve Fars dilinde kere "tereyağı" ile birlikte tere "bitki" sözcüğü de kullanılmaktadır. Yine Türkiye Türkçesinde de tere(yağı) sözcüğünün ile birlikte bir de bitki anlamında tere sözcüğü bulunur.

\begin{tabular}{|l|l|l|l|l|}
\hline & Biçim & Anlam & Biçim & Anlam \\
\hline AZ. & Kere & Tereyağı & Tere & Bitki \\
\hline İran Türk Ağız. & Kere & Tereyağı & Tere & Bitki \\
\hline Far. & Kere & Tereyağı & Tere & Bitki \\
\hline & $\downarrow$ & $\downarrow$ & $\downarrow$ & $\downarrow$ \\
\hline Tr. Tir. & Ter(yağı) & Tereyağı & Tere & Bitki \\
\hline
\end{tabular}

Çizelge: 8

Yukarıdaki çizelgeden de anlaşıldığı üzere tere (yağı) sözcüğü, biçim yönünden bitki anlamındaki Farsça tere ile ortak ses değerlerine sahip olsa da anlam yönünden Farsça kere "tereyağı" ile ortak noktada buluşmaktadır. Kanaatimizce tere sözcüğünün Türkiye Türkçesinde bitki ve yağ olmak üzere iki anlamı bulunmuştur. Daha sonra yağ anlamında kullanılan tere ile bitki anlamındaki tere arasında farklılık yaratmak için bu sözcüğün sonuna yă̆ sözcüğü eklenerek tere(yă̆ı) ortaya çıkmıştır. Ancak bitki anlamındaki tere sözcüğ̈̈ yalın biçimde varlığını sürdürmüştür. Böylece tereyağı sözcüğünün ilk

$4 \quad$ Tarafımızdan araştırılmıştır. 
anlamlı parçası olan tere ile Farsçada, Azerbaycan ve İran Türk değişkelerinde kullanılan kere sözcügünün $t$ - k- denkliği bağlamında ortak kaynaktan çıtı̆̆̆ söylenebilir.

\section{Kırık Terek}

Yeni Fars dilinde terek ترك; çatlak (Moin 2002: 447), terekî-; çatlamak (Moin 2002: 448) anlamında kullanılır. Farsça köken bilgisi çalışmalarından Kâşânî Sözlüğü ile Nourai Sözlüğü’nde terek "çatlak” ve terekî- "çatlamak" sözcüklerine yer verilmemiştir. Avestaca, Eski Farsça ve Yeni Farsçada kullanılan fiillerin kökenini inceleyen Râhnémâ-yé Rîşé-yé Félhâ-yé İranî "İranî Fiillerin Kökeni Kılavuzu” adlı çalışmada da tereki- "çatlamak" sözcüğü yer almamıştır. Bu durum, Farsça terekī-/terek sözcüklerinin herhangi bir Hint-Avrupa köküne bağlanamadığını gösterir.

$T$ - k- denkliği kapsamında ele alındığında Türkçe kırık ile Farsça terek sözcüklerinin ortak kaynaktan çıtığı söylenebilir. Bu ikili arasında görülen $\imath / e$ karşıtlığı ise Türkçeden Farsçaya geçen sözcüklerde sık rastlanan bir ses olayıdır: Tür. kātık> Far. kāték "yoğurt" (Moin 2002: 1209); Tür. kāāyık> Far. kāyék "kayı" (Moin 2002: 1219); Tür. kayın> Far. kāyen "kayınbirader" (Moin 2002: 1222); Tür. klbrak > Far. kebrāḳ "hızlı" (Moin 2002: 1222); Tür. ḳrḳı Far. kerḳī "atmaca kuşu”(Moin 2002: 1234).

Türkçe Sözlük’te kırık sözcüğünün anlamlarından biri kırılmış olan demektir. Türkçe kırık sözcüğünün krr- sözcüğünden üretildiği açıktır. Orta Türkçede kazımak, bir şeyi kökünden çıkarmak, kırmak (DLT 1998: 317) anlamında geçen kır-, çağdaş Türk değişkelerinde kurmak, kazımak, tıraş olmak anlamlarında kullanılmaktadır (Starostin, Dybo vb. 2003: 679). Türkçe krr-sözcügü çizelgede gösterilen Tunguz, Moğol ve Japonca örneklerle ortak kökene bağlanmıştır (Starostin, Dybo vb. 2003: 679).

\begin{tabular}{|c|c|c|c|}
\hline Dil & Değişke & Biçim & Anlam \\
\hline \multirow{2}{*}{$\begin{array}{l}\text { Ön Tunguzca *kire: kly-, } \\
\text { kopar- }\end{array}$} & Orok Tun. & Keren- & Kıy- \\
\hline & Nanai Tun. & Kermē- & Kopar- \\
\hline \multirow{5}{*}{$\begin{array}{l}\text { Ön Moğolca *kiru-: kly-, } \\
\text { küçük kes- }\end{array}$} & Orta Moğ. & Keru & Küçük parça \\
\hline & Yazı Moğ. & Kiru- & Kıy-, küçük kes- \\
\hline & Halha Moğ. & Xar- & Kıy-, küçük kes- \\
\hline & Buryat Moğ. & kirma- & Kıy-, küçük kes- \\
\hline & Kalmuk Moğ. & kur- & Kıy-, küçük kes- \\
\hline \multirow{5}{*}{$\begin{array}{l}\text { Ön Türkçe }{ }^{*} \text { Kır-: kır-, kly-, } \\
\text { kazl- tıraş ol- }\end{array}$} & Orta Tür. & Qir- & Kıy- \\
\hline & Tür. Az, Gag. Hal. Tür. & Kir-, qur- & Kur- \\
\hline & $\begin{array}{l}\text { Sal. Öz. Uyg. Tat. Krg. Kaz. KKalp. Nog. } \\
\text { SUyg. Oyr. Tuv. Tof. Tür. }\end{array}$ & Qir-, qir- & Kly-, tıraş ol- \\
\hline & Hakas Tür. & $X i r$ & Kiy-, tıraş ol- \\
\hline & Trkm. Krm. Baş. Kum. Tür. & Qir- & Kur-, kıy-, tıraş ol- \\
\hline
\end{tabular}




\begin{tabular}{|l|l|l|l|}
\hline & Yak. Dolg. Tür. & Kirıy- & Kes- \\
\cline { 2 - 5 } & Çuvaş Tür. & xər- & Kır- \\
\hline \multirow{3}{*}{ Ön Japon *kìr-: kes- } & Eski Jap. & Kyir- & Kes- \\
\cline { 2 - 5 } & Orta Jap. & Kìr- & Kes- \\
\cline { 2 - 4 } & Tokyo Jap. & Kír- & Kes- \\
\cline { 2 - 4 } & Kagoshima Jap. & Kìr- & Kes- \\
\cline { 2 - 4 } & Kyoto Jap. & Kìr- & Kes- \\
\hline
\end{tabular}

Çizelge: 9

Türkçe kırk- ve kırp- sözcükleriyle kır- arasındaki ses ve anlam ilişkisi, bu üçlünün ortak kaynaktan çıktığını gösterir. Türkçe Sözlük’te kırp-; kesmek, kırmak (TS 1998: 1302), kurk-; bir şeyi uçlarından kesmek, (saç, sakal, tüy için) kesmek (TS 1998: 1300) anlamında geçer. Ayrıca Türkiye Türkçesindeki kırp- ile Hakas Türkçesindeki tırba- arasında da t- k- denkliği saptanmıştır (Kızılözen 2018: 272).

\section{Kırıs- Terenc-}

Farsçada terenc ترنج; kurışık, terencî- ترنجين; kırışmak anlamında kullanılır (Moin 2002: 448). Bu ikilinin torenc ve torencî- biçiminde birer değişeni bulunur. Kâşânî çalışmasında bu sözcüklere yer verilmemiştir. Nourai çalışmasında terenc sözcügü yer almamıştır. Terencî- veya torencî- biçimlerine de özel başlık atılmamıştır, ancak tenciden- "çekmek" sözcüğünün incelenmesinde terencî- biçimi de parantez içine gösterilmiştir. Râhnémâ-yé Rişseha-yé Fe'lhâ-ye Îrânî "İranî Fiillerin Köken Kılavuzu" adlı çalışmada da terencī- "krıışmak" sözcüğü yer almaz.

Azerbaycan Türkçesinde qırış; bir şeyin büküldüğü, katlandiğı yerde kalan iz anlamında kullanılır (Orucov, Abdullayev vb. III 2006: 142). Türkçe Sözlük’te karlş-; bir yüzeyin düzgünlüğü bozulmak, kırışık olmak anlamında geçerken kurışık; kırışmış olan anlamında kaydedilmiştir. Türkçe kurış- ile Farsça terenc- sözcüklerinin ses ve anlam değerleri dikkate alındığında bunların ortak kaynaktan çıktığı söylenebilir. Kırış- ile terenc/terencî- sözcükleri arasında $t$ - $k$ - denkliğinin yanı sıra bir de $-e->-\iota^{-}$ değişikliği var. Türkçeden Farsçaya geçen sözcüklerde ortaya çıkan ünlü değişmelerinden biri, Türkçe $\imath$ ünlüsünün $e$ ünlüsüyle yer değiştirmesidir: Tür. kāttk> Far. kāték "yoğurt" (Moin 2002: 1209); Tür. kāyık> Far. kāyék "kayı" (Moin 2002: 1219); Tür. kayın> Far. kāyen "kayınbirader" (Moin 2002: 1222); Tür. kıbrak > Far. kebrāk "hızlı" (Moin 2002: 1222); Tür. ḳrḳı> Far. kerḳī "atmaca kuşu”( Moin 2002: 1234).

\begin{tabular}{|c|c|c|c|c|c|c|c|c|c|c|}
\hline Dil & Biçim & Anlam & Biçim & Anlam & Biçim & Anlam & Biçim & Anlam & Biçim & Anlam \\
\hline Tür. & kurık & Kırık & ker- & kır- & kurk- & tıraş ol- & Kirış & kırışık & kırış- & kırış- \\
\hline Far. & terek & Çatlak & terekî- & çatla- & terāşî̀- & tıraş ol- & terenc & kırışık & terencī- & kırış- \\
\hline
\end{tabular}

Çizelge: 10 


\section{Küç Tūş}

Farsçada tūş توش; güç, kuvvet anlamında kullanılır (Moin 2002: 499). Farsça kökenbilgisi çalışanlarında bu sözcük yer almamıştır. Bu sözcüğe Farsça kökenbilgisi çalışmalarında yer verilmemesi onun Hint-Avrupa kökenli olmadığını gösteriyor.

Farsça tūş "güç" ile Türkçe küç "güç" arasında bir $t$ - k- denkliği vardır. Altay dillerinden Tunguz, Moğol ve Kore dillerinde Türkçe küç sözcüğü ile ortak kaynaktan çıktığı düşünülen örneklerin kullanılıyor olması bu sözcügün Türkçe olduğunu gösteriyor (Starostin, Dybo vb. 2003:730).

\begin{tabular}{|c|c|c|c|}
\hline Dil & Değişke & Biçim & Anlam \\
\hline \multirow{6}{*}{$\begin{array}{l}\text { Ön Tunguzca: *kusū-: savaş-, } \\
\text { kavga, güç }\end{array}$} & Negidal & Kusun & Güç \\
\hline & Mançu & Xusun & Güç \\
\hline & Ulça & kusu(n) & Güç \\
\hline & Orok & kusu(n) & Güç \\
\hline & Nanai & Kusũ & Güç \\
\hline & Udehe & Kûhi & Güç \\
\hline \multirow{3}{*}{ Ön Moğolca *küči-n: güç } & Orta Moğ & koçer- & Güç \\
\hline & Yazı Moğ. & Kuçi & Güç \\
\hline & $\begin{array}{l}\text { Halha, Buryat, Kalmuk, Dagur, } \\
\text { Ordos, Dongxian }\end{array}$ & $\begin{array}{l}\text { Xüç, xüşe(n), Küçn, } \\
\text { Kuçi, güçi(n), Kuçie }\end{array}$ & Güç \\
\hline \multirow{12}{*}{ Ön Türkçe *gǚ̌c: güç } & Eski, Orta Tür. & Küç & Güç \\
\hline & Tür. Az. Gag. & güç, güc & Güç \\
\hline & Trkm & $G \overline{u ̈ c}$ & Güç \\
\hline & Hal. & Kïiç & Güç \\
\hline & Öz. Uyg. Kum. Kur. Oyr. & Küç & Güç \\
\hline & Tat. & Köç & Güç \\
\hline & Baş. & Kös & Güç \\
\hline & Kaz. KKalp. Nog. Tof. Tuv. Şor. & Küş & Güç \\
\hline & S. Uyg. & Kuş & Güç \\
\hline & Tuva & Xamıq & Güç \\
\hline & Hakas & Küs & Güç \\
\hline & Yak. Dolg. & $K \bar{u} s$ & Güç \\
\hline
\end{tabular}




\begin{tabular}{|l|l|l|l|}
\hline \multirow{2}{*}{$\begin{array}{l}\text { Ön Korece *kočč́k: aşı̈rı, çok } \\
\text { güce fazla }\end{array}$} & Orta Kor. & koçắk-hă - & Güç \\
\cline { 2 - 4 } & Çă̆daş Kor. & Koçak & En fazla \\
\hline
\end{tabular}

Çizelge: 11

Bu ikili arasında görülen -ş, -ç değişikliği de yine Türkçenin kendi içinde görülen -ç>-ş değişimiyle açıklanabilir. Küç sözcügünün Kazak, Karakalpak, Nogay, Tofalar, Tuva ve Şor değişkelerinde küş biçiminde kullanılması bu bağlamda örnek verilebilir (Starostin, Dybo vb. 2003:730).

\section{Külek Dūléx}

Farsçada dūléh, dūlex, dūlāx دولها, دولغ, دولاخ değişenleri toz, firtına anlamında kullanılır (Emîd 2010: 542). Ayrıca kūlāk sözcüğü de Farsçada firtına demektir (Emîd 2010: 859). Burada dūlāx ile kūlāk arasındaki $d-(<\mathrm{t}) \sim k$ - denkliği dikkat çekmektedir. Farsça kökenbilgisi çalışmalarından Kâşânî ve Nourai sözlüklerinde dūléh, dūlex, dūlāx ve kūlāk biçimlerinden hiçbirine değinilmemiştir. Özellikle Kâşânî Sözlüğü'nde "Hint-Avrupa kökenli olduklarından emin olmadiğımız sözcükleri çahssmaya almadık” ibaresi bu sözcüğün Hint-Avrupa kökenli olmadığı konusunda ipucu veriyor.

Emîd Sözlügüu'nde kūlāk sözcüğünün Türkçe olduğu belirtilmiştir.5 Türkçede kūlāk sözcügünü ses ve biçim olarak karşllayan, külek sözcüğüdür. Külek sözcüğü Azerbaycan Türkçesi (Orucov, Abdullayev vb. II 2006: 775) ile Türkiye Türkçesi ağızlarında (DERS 2009: 3029) yel, İran Türk ağızlarından Halhal ağzında firtına anlamında kullanılır. Türk değişkelerinde külek biçiminin yanı sıra tülek biçimi de vardır. Türk değişkelerinden Şor değişkesinde tülek, Azerbaycan Türkçesi ağızlarında tülex ve Türkmen değişkesinde tüveley biçimleri kasırga anlamında kullanılmaktadır (Starostin, Dybo vb. 2003: 1467).

Farsça dūlax "firtına" kūlāk "fırtına"

Türkçe tülek "kasırga" külek "firtına"

Türk değişkelerinde kullanılan tülek, tülex ve tüveley değişenlerinin Ön Türkçe *tüge-le- "kasırga, kar fırtınası" biçiminden, Ön Türkçe biçiminin de Ana Altay dilinde toz ve firtına anlamında kullanıldığı düşünülen *t ŭge sözcüğünden çıtığı düşünülmüştür. Araştırmacılar Moğol dillerinde ince yağan kar ve toz kar anlamında kullanılan tujayu, tujil-dasu, tujldas, tujū biçimleri ile Tunguz dillerinde soğuk ve kış anlamında geçen tuye, tugi, tuweri, tukusu, tuje-yi , tu-e-li, tewekse, tue, teweske, tuwe, tukse, tue, tokso, tuwe, tue, toko, tue, tukču biçimlerinin Ana Altay dilindeki tahminî *t'ŭge sözcüğüne bağlamaktadırlar (Starostin, Dybo vb. 2003: 1467).

\section{Tamak Kāméh}

Farsçada kāmeh كامه ile kısa biçimi olan kām sözcüğünün iki anlamı vardır. İlk anlamı istek, arzu, ikinci anlamı ise ă̆ız ve ağızın üst bölümü olan damak (Emîd 2004: 961-62)'tır. Farsça kāméh sözcüğünün ikinci anlamı, Türkçe damak sözcügünün anlamı ile aynıdır. Yeni Farsçada kāmeh olarak geçen sözcük, Orta Farsçada kāmek olarak kullanılmıştır. Farsça kökenbilgisi çalışmalarından Ferheng-é Rîşéhâ-yé Hénd o Ûrûppâ̂̀-yé Zebân-é Fârsî "Fars Dilinin Hint-Avrupa Kökenliler Sözlüğü" çalışmasında Farsçada istek ve dilek anlamında kullanılan kām, kāméh (Kâşânî 2005: 397) üzerinde durulmuş ancak damak anlamındaki kāméh/kām sözcüğüne yer verilmemiştir. Daha önce de belirttiğimiz gibi

5 https://www.vajehyab.com/amid/ كو لاك/ 
Kâşânî’nin çalışmasında Farsçada kullanılan ancak Hint-Avrupa kökeni olmayan sözcüklere yer verilmediği vurgusu yapılmıştır. Damak anlamındaki kām sözcüğünü çalışmasına alan Nourai, bu sözcükle aşă̆ıdaki kavramlar arasında ilişki kurmuştur (Nourai 2013: 262).

\begin{tabular}{|l|l|l|l|}
\hline Dil & Eski Farsça & Yeni Farsça & Sanskritçe \\
\hline Biçim & çem & çemiden, cemeti & çemeti \\
\hline Anlam & yutmak & yutmak, içmek & yutmak \\
\hline
\end{tabular}

Çizelge: 12

Öteki çalışmalarda da damak anlamındaki kāméh/kām sözcüğü incelemeye alınmamıştır. Farsça kökenbilgisi çalışmalarında kām sözcüğünün Hint-Avrupa kökenli olduğunu gösterecek yeterli kanıt sunulmamaktadir:

I. Önemli kökenbilgisi çalışmalarında bu sözcüğe yer verilmemiştir.

II. Sadece bir kökenbilgisi çalışmasında yer alan bu sözcükle ilgili Avrupa dillerinden herhangi bir örnek gösterilmemiştir.

III. Sanskritçe ve Eski Farsça çem- "yutmak" ile kām "damak" arasında köken bağı ilişkisi kurmak, bu sözcüğün Hint-Avrupa kökenli olduğunu göstermez. Sanskritçe Hint-Avrupa dillerinden biridir. Söz konusu sözcük Ön Türkçeden Sanskritçeye geçmiş olabilir. Ancak bu konu çalışmamızın sınırlarını aştığından üzerinde durulmayacaktır.

Orta Farsçadaki kāmak ile Halaç Türkçesindeki kamak sözcüklerinin ses ve anlam değerleri örtüşüyor. Halaç Türkçesinde kamak; damak anlamında kullanılmaktadır. ${ }^{6}$ Halaç Türkçesinde kullanılan damak anlamındaki kamak ile ilgili ileri sürülecek karşı görüssleri şimdiden tahmin etmek mümkündür. "Halaç Türkçesi Farsçanın yoğun etkisi alttnda olduğundan Halaç Türkçesindeki tamak sözcüğünün ilk ünsüzü Farsça kāméh sözcüğünün baskısıyla k’leşmiştir”, denebilir! Açıcçası damak sözcüğünün Halaç Türkçesinde kamak olarak kullanıldığını öğrendiğimizde bizim de tepkimiz böyle olmuştu. Ancak:

I. Halaç Türkçesinde kamak olarak kullanılan sözcük eski Türkçede tamak olarak geçer. Orta Farsçadaki kāmek ve Halaç Türkçesinde kamak ile Eski Türkçedeki tamak arasında biçim yönünden farklılık, anlam yönünden ortaklık görülüyor. Bu ikiliyi birbirinden ayıran özellik, birinde $t$-; ötekisinde $k$ - ünsüzünün geçmesidir.

II. Damak sözcüğünün $k^{\prime}$ li olması sadece Halaç Türkçesine özgü bir durum değildir. Bu sözcüğün başka Türk değişenlerinde $k$-li biçimleri bulunur. Ayrıca Türkçe tamak ile kökteş sözcüklerin Altay dillerinde de $q$-'ll, $x$-'li, $k$-li biçimlerine rastlamak da mümkündür. Türkçe tamak "damak" sözcügüuyle ortak kökenden çıktığı düşünülen sözcüklerin Türkçe dışındaki Altay dillerinde bulunması (Starostin, Dybo vb. 2003: 806) bu sözcüğün Türkçe kökenli olduğunu, Türkçeden Farsçaya geçtiğinin kanıtıdır.

\footnotetext{
$6 \quad$ Halaç Türkçesinde damak sözcüğünün kamak biçiminde kullanıldığını Halaç Türkçesi üzerine yaptığımız araştırmalar sirasında öğrendi idik. 


\begin{tabular}{|c|c|c|c|}
\hline Dil & Değişke & Biçim & Anlam \\
\hline \multirow{4}{*}{$\begin{array}{l}\text { Ön Tunguzca *xopa-: burun, teknenin } \\
\text { ön kısmı, burun köprüsü (kanall) }\end{array}$} & Mançu & Xōqo & teknenin ön kısmı \\
\hline & Ulça & Xōqo & teknenin ön kısmı \\
\hline & Nanai & Qontoro & Burun \\
\hline & Oroç & Xojko & teknenin ön kısmı \\
\hline \multirow{7}{*}{ Ön Moğolca *ka[m]ar: burun } & Orta Moğ & Qabar & burun \\
\hline & Yazı Moğ. & Qabar & Burun \\
\hline & Buryat & Xamar & Burun \\
\hline & Kalmuk & Xamr & Burun \\
\hline & Dongxian & Qava & Burun \\
\hline & Baoan & Xor & Burun \\
\hline & Şira-Yuğur & Xavar & Burun \\
\hline \multirow{9}{*}{$\begin{array}{l}\text { Ön Türkçe *K(i)an-(ir)-: burun, tıkan- } \\
\text {, genizden konuş-, gaga, burunlu, burun } \\
\text { köprüsü (kanalı) }\end{array}$} & Orta Tür. & Qayraq & Damak \\
\hline & Halaç & Kamak & Damak \\
\hline & Kirgiz & Qayiriq & hirlttı, horlama \\
\hline & Trkm. & Gayštravuq & burun boşluğu \\
\hline & Baş. (ağız) & Qayyiriq & sert damak \\
\hline & Sarı Uygur & Qayriq, qarq & burun \\
\hline & Tofalar & $X \bar{a} j$ & burun, gaga \\
\hline & Yakut & Xopurū, xayir & burun köprüsü \\
\hline & Tuva & $X \bar{a} j$ & gaga \\
\hline \multirow{5}{*}{ Ön Japonca *kan-l-: koklamak } & Eski Jap. & Kag- & kokla- \\
\hline & Orta Jap. & Kág- & kokla- \\
\hline & Tokyo & Kàg- & kokla- \\
\hline & Kyoto & Kág- & kokla- \\
\hline & Kagoşima & Kág- & kokla- \\
\hline Ön Korece *koh: burun & Çağdaş Kor. & kó (kóh) & burun \\
\hline
\end{tabular}

Çizelge: 13 


\section{Töş Keş}

Farsça sözlüklerde keş كش sözcügünün anlamlarından biri göğüs olarak verilmiştir (Moin 2002: 1359). Nourai Sözlüğü’nde yer almayan keş, Kâşânî çalışmasında aşağıdaki sözcüklerle ilişkilendirilmiştir (Kâşânî 2005: 405).

\begin{tabular}{|l|l|l|l|l|l|}
\hline \multicolumn{2}{|l|}{ Hint-İran Dilleri } & $?$ & Latince & Coxa & Popo, kalça \\
\hline Avestaca & Keşe & $?$ & E. Almanca & Hāhsina & Parmak boğumu \\
\hline Pehlevice & Keş & $?$ & Almanca & Hachse & Parmak boğumu \\
\hline Beluçça & Keşe & $?$ & E. İrlandaca & Coss & Ayak \\
\hline Sanskritçe & Kaksa, kakşa & & Gallerce & Coes & $?$ \\
\hline & & & Çilleri \\
\hline
\end{tabular}

Çizelge: 14

Kâşânî’nin Avrupa dillerinden gösterdiği örneklerle Farsça keş arasındaki ses ve anlam ilişkisi sağlam değildir. Ayrıca öteki kökenbilgisi çalışmalarında bu sözcüğün yer almaması, söz konusu sözcüğün HintAvrupa kökenli olmadığını gösteriyor.

Türkçe Sözlük'te döş sözcüğü göğüs, anlamında kullanılır. Eski ve Orta Türkçede töş biçiminde kullanılan bu sözcüğün çağdaş Türk değişkelerinde çeşitli biçimleri bulunur. Ön Türkçede *dṓl biçiminde kullanıldığı düşünülen bu sözcüğün Mançu Tunguzcasında atın göğsü anlamında kullanılan tulu sözcüğü ile ortak kaynaktan geldiği ileri sürülmektedir (Starostin, Dybo vb. 2003: 1456).

\begin{tabular}{|l|l|l|l|}
\hline Dil & Değişke & Biçim & Anlam \\
\hline \multirow{4}{*}{ Ön Tunguzca *tulu: at göğsü } & Mançu & Tulu & Atın göğsü \\
\hline \multirow{5}{*}{ Ön Türkçe *dōí: döş } & Eski, Orta Tür. & Töşs & Döş \\
\cline { 2 - 4 } & Tür. Az. Tof. Tür. & Döşs & Döşs \\
\cline { 2 - 4 } & Trkm & Döş̧ & Döş \\
\cline { 2 - 4 } & Özbek Tür. & Tọ̧s & Döş \\
\cline { 2 - 4 } & Uyg. Krm. Krg. Kum. Şor. Oyr. Tuv. & Töşs & Döş \\
\cline { 2 - 4 } & Tat. Baş. & Tüşs & Döş \\
\cline { 2 - 4 } & Kaz. KKlp. Nog. SUyg. Hak. & Tös & Döş \\
\cline { 2 - 4 } & Çuvaş & Çül-lək & Döş \\
\cline { 2 - 4 } & Yakut, Dolgan & Tüös & Döş \\
\hline
\end{tabular}

Çizelge: 15 


\section{Sonuç}

K- ünsüzüyle başlayan kimi Farsça sözcüklerin anlam değişikliğine uğramadan Türkçede t- ile kullanıldığı görülür. Türkçe-Farsça sözcüklerde görülen söz başı t-/k- sorunu, bir ünsüz değişimi olarak ele alınabilirdi. Ancak Türk değiş̧kelerinde saptanan söz başı $t$ - $k$ - denkliği, Türkçe ve Farsça sözcüklerde görülen $t$-/ $k$ - değişikliğinin bir ünsüz değişiminden kaynaklanmadığını gösteriyor. Karşılaştırmalı yöntemin kullanıldığı bu incelemede Türkçe ile Farsçada söz başı t- k- denkliği bulunan on çift sözcük tespit edilmiştir. Bu sözcüklerden Farsça olanların Hint-Avrupa dillerindeki kökleri araştırıldı. Türkçe olanların da Altay dillerinde kökteşlerinin bulunup bulunmadığına bakıldı.

Türkçe-Farsça sözcüklerde görülen t-/k- değişikliği, Türkçenin kendi içinde görülen bir ünsüz denkliğinin Türkçeden Farsçaya geçen sözcüklerdeki tezahürüdür. Başka bir deyişle söz konusu sözcükler Türkçenin herhangi bir eski değişkesinde t-'li biçimiyle kullanılırken bir başka değişkesinde k-'li biçimiyle kullanılmıştır. Böylece Farsçanın alıntı yaptığı Türk değişkesi, söz konusu sözcüğü k-li biçimiyle kullandıysa Farsçaya da k-'li olarak geçmiştir. Yine Farsçanın alıntı yaptı̆̆ı Türk değişkesinde söz konusu sözcük t-li biçimiyle kullanıldıysa Farsçaya da t-li olarak girmiştir. İncelememizde t- kdenkliği kapsamında ele aldığımız örnekler şöyledir:

\begin{tabular}{|c|c|c|c|}
\hline \multicolumn{2}{|c|}{ Türkçe } & \multicolumn{2}{|c|}{ Farsça } \\
\hline Biçim & Anlam & Biçim & Anlam \\
\hline Kabar & Kabar & Tāvel & Kabar \\
\hline Kaç- & $\mathrm{K}$ açmak & Tāç- & Kaçmak \\
\hline Kapak & Kapak & Tābeh & Tava \\
\hline Tere(yağı) & Tereyağı & Kere & Tereyağı \\
\hline Kirık & Kırık & Terek & Çatlak \\
\hline Kırış- & Kırışmak & Terenci- & Kırışmak \\
\hline Küç & Güç & Tūş & Güç \\
\hline Külek & Firtına & Dūléx & Firtına \\
\hline Tamak & Damak & Kām(éh) & Damak \\
\hline Töş & Döş & Keş & Döş \\
\hline
\end{tabular}

Çizelge: 16

Kaynakça

Ârîyânpûr Kâşânî, Menûçehr (2005). Ferheng-é Rîşéhâ-yé Hénd o Ûrûppâî-yé Zebân-é Fârsî "Fars Dilinin Hint-Avrupa Kökenliler Sözlüğü”, Cehâd-é Dânéşgâhî Yay. Isfahan.

Balcı, Mustafa (2014). Türkçe-Farsça İlişkileri Türkçenin Farsça Üzerindeki Etkilerine Dair Bir Inceleme, Çizgi Kitabevi Yay., Konya.

Baskakov, N. A. (1991). Gagauz Türkçesinin Sözlüğü, (Çev. İsmail Kaynak, Mecit Doğru), Türk Kültür Bakanlığı Yay. Ankara.

Behrâmî, Ehsân. (1989). Ferheng-i Vâjeh-yé AEvestâ̂̃ “Avesta Kelimeleri Sözlüŭü”, Tahran. 
Bolganbayev, Esed; Bayınkol Kaliyev vb. (1999). Kazak Tilinin Sözdigi, Dayk Pres Yay., Almatı.

Caferoğlu Ahmet (1993). Eski Uygur Türkçesi Sözlüğü, Enderun Kitapevi, Ankara.

Cheung, Johnny (2007). Etymological Dictionary of the Iranian Verb, Leiden - Boston.

Derleme Sözlüğ ü (Türkiye Türkçesi Ağızları Sözlüğü), TDK Yayınları, 2009.

Doerfer, Gerhard (1963). Türkische und mongolische Elemente im Neupersischen I, II, III, Wiesbaden.

Emîd, Hasan (2004). Ferheng-e Emîd "Emîd Sözlüğü", Emir Kebir Yay. Tahran.

Esverî, Eddî Şîr Keldânî (2007). Vâjehâ-yé Fârsī-yé Erebī Şode "Arapçalaşmış Farsça Kavramlar", Farsçaya Çeviren: Hemîd Tebîbîyân, Emir Kebir Yay. Tahran.

Ferehveşî, Behrâm (2002). Ferheng-é Zebân-é Pehlevî “Pehlevi Dili Sözlüğü”, Tahran Üniversitesi Yay. Tahran.

Ganiyev, Fuat, Rifjat Ahmediyanov, vb. (1997). Tatarca - Türkçe Sözlük, Insan Yay., Kazan-Moskova. Gharib, B. (2004). Sogdian Dictionar, Ferhengân Yay. Tahran.

Gülensoy, Tuncay (2007). Türkiye Türkçesindeki Sözcüklerin Köken Bilgisi Sözlüğü, TDK Yay., Ankara. Hânlerî, Pervîz N. (1998). Târiḥ-é Zebân-é Fârsî II "Fars Dili Tarihi II", Ferdos Yay. Tahran.

Hassandoust, Mohammad (2016). Farshang-é Rīşéşenāxtī-yé Zebān-é Fārsī I- II- III- IV-V, "Fars Dili Kökenbilgisi Sözlüğü I, II, III, IV, V”, Āsār Yay. Tahran.

Jackson, A. V. Williams (1892). Avesta Grammar İn Comparison With Sanskrit, Stuttgart.

Karaağaç, Günay (2003). Moğolca Türkçe Sözlük I, II, TDK Yay., Ankara.

Kızlözen, Cihangir (2018). Türk Dilinde T- K- Denkliği, Mavi Atlas Dergisi, Gümüşhane Ün. Yay.

Korece-Türkçe Türkçe-Korece, Fono Yay., İstanbul, 2017.

Moîn, Mohammed (2002). Ferheng-e Moîn "Moin Sözlüğü" Edenâ Yay. Tahran.

Mokaddem, Mohemmed (1963). Râhnémâ-yé Rîşeha-yé Fe'lhâ-ye Îrânî "İranî Fiillerin Kökeni Kılavuzu", İlmî Matbuat Yay. Tahran.

Nefîsî, Ali Ekber (Nâzém-ol Etbâ) (1976). Ferheng-i Nefisîi “Nefîsî Sözlüğü”, Heyyâm Yay., Tahran.

Nourai, Ali (2013). An Etymological Dictionary of Persian, English and other Indo-European Languages I, II, Xlibris Yay. Amerika.

Orucov, Eliheyder, Behruz Abdullayev, Nergiz Rehimzadeh (2006). Azerbaycan Dilinin İzahlı Lügati, Bakü.

Pokorny, Julius (2007). Proto-Indo-European Etymological Dictionary, elektronik kitap.

Starostin, S. A.; A. V. Dybo, O. A. Mudrak (2003). An Etymological Dictionary of Altaic Languages I, II, III, Brill Yay. Hollanda.

Toparl, Recep; Hanifi Vural vb. (2014). Kıpçak Türkçesi Sözlüğü, TDK Yay. Ankara.

Türkmen Dilinin Düşündirilişli Sözlügi, Aşkabat, 2016.

Vasiliev, Yurıy (1995). Türkçe - Sahaca (Yakutça) Sözlük, TDK Yay., Ankara.

Yudahin, K. K. (2011). Kırgız Sözlüğ̈̈, TDK Yay. Çeviren: Abdullah Taymas, Ankara. 